\title{
Impact of Farm Mechanization on Crop Productivity in Sub-Tropical Areas of Jammu and Kashmir
}

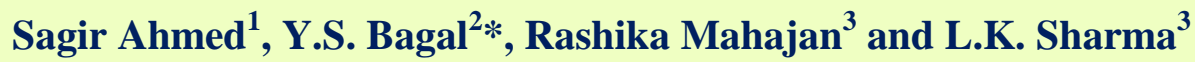 \\ ${ }^{1}$ J.A.E.O, Directorate of Agriculture, Jammu, J\&K, India \\ ${ }^{2}$ Assistant Professor, RIMT University, Punjab, India \\ ${ }^{3}$ Division of Agricultural Extension Education, SKUAST-Jammu, J\&K, India \\ *Corresponding author
}

\section{Keywords}

Adoption, Farm Mechnanization,

Productivity,

Tillage equipments

Article Info

Accepted:

10 April 2020

Available Online:

10 May 2020

\section{A B S T R A C T}

Mechanization is important and useful as it takes place in almost every face of human endeavor to meet required target and to boost efficiency. This study was conducted to find the impact of the variables on the adoption of farm mechanization. Multi-stage random sampling technique was employed for selection of the 160 respondents. Pretested interview schedule was used for the collection of data. Linear regression model use used to analyse the factors affecting the productivity of wheat and rice crop. It was found that the variable affecting rice productivity was primary tillage $\left(\mathrm{R}^{2}=0.19, p=0.001\right)$, variables effecting wheat productivity were use of irrigation, primary tillage and use of rotavotor. The study may be useful in improving the design and development of new farm machines and also for incorporating suitable changes in the existing design.

\section{Introduction}

Farm mechanization implies the use of various power sources, improved farm tools and equipments, with a view to reduce drudgery of human beings and draught animals, thereby increasing crop production and productivity and is advantageous as compared to manually working on the field. Past studies on efficiency of farm mechanization revealed that by mechanization a farmer can save seed (15-20\%), fertilizer
(20-30\%), time (20-30\%), labour (5-20\%), increasing cropping intensity (10-15\%) and higher productivity (15-20\%) (Singh et al., 2008). Singh et al., (2008) also reported that the level of mechanization of different operations in Indian agriculture are: soil working and seed bed preparation (40\%), seeding and planting (29\%), plant protection (34\%), irrigation (37\%), harvesting and threshing of wheat and rice $(60-70 \%)$ and for other crops less than five percent. In primary tillage, machines like rotavotor, disc harrow, 
disc plough and cultivator can invariantly be used in place of traditional methods followed by farmers resulting in saving of time, cost and energy. In sowing and intercultural operation, with the mechanization timeliness in sowing can be achieved by the use of seedcum-fertilizer drill, potato planter, sugarcane planter and paddy transplanter. When timely operation is performed in a mechanized way, the area to be cultivated will be much with in a limited time and it will boost food security in the nation. All the operations are mechanized in nature and they enhance sustainable food production. The quantity and quality of food products to be produced which will ultimately makes food get to the reach of millions of people will be many when mechanization is employed or utilized in carrying out these. All the farm machineries, equipments and implements plays vital role in the enhancement of food production, if properly utilized and made affordable within the reach of small and medium scale farmers. Keeping in view all the observable benefits of farm mechanization, the present study on the adoption of farm mechanization and their impact on productivity of wheat and rice crop was conducted.

\section{Materials and Methods}

The present study was conducted in the subtropical areas of Jammu district of the J\&K state. All the eight blocks of Jammu district were selected for the study. So that the research finding can be generalized for the whole of the Jammu district. Two villages from each block were selected randomly without replacement. A list of farmers of the sixteen villages was prepared by taking the help of Sarpanches and government officials. The criteria for preparing the list of farmer was that he/she should possess a minimum 4 kanals of land and which he/she is cultivating.
From the list prepared ten farmers were randomly selected without replacement. Thus the sample for collecting the data was 160 . The data was analysed by linear regression model was applied for determining the factors affecting productivity of wheat and rice crop.

\section{Results and Discussion}

A few respondents i.e. cultivator by 10 percent and country plough by 18 percent possess primary tillage equipments. Further in case of secondary tillage very few of the respondents i.e. rotavator $(2 \%)$, leveler $(1 \%)$ and planker $(4 \%)$ of the respondents possess it. (Table 1).The finding get support from Nagaraj et al., (2013) who also found same results.

In case of equipments used for intercultural operations, long handle hoe, double end hoe and bongardi and were owned by 44, 22 and 79 percent of the respondents respectively. The respondents also owned $\mathrm{V}$ blade hoe (98\%) and Gudnu (100. Since majority of these intercultural equipments are of immense importance in intercultural operations and are not so expensive so majority of the respondents has its possession. 25 percent of the respondents own knapsack sprayer it because knapsack sprayer is very essential equipment for insect pest control. None of the respondent own sowing and transplanting equipment because, majority of the respondents manually transplanting the rice and were broadcasting the maize and wheat seed, so the equipments were not possessed by the respondents (table 1).

With regards to productivity of rice crop all of the respondents who were growing rice used tractor for tillage operation and its productivity was $32.69 \mathrm{q} / \mathrm{ha}$. 
Table.1 Adoption of farm equipments by the farmers

\begin{tabular}{|c|c|}
\hline Equipments & Total $(n=160)$ \\
\hline \multicolumn{2}{|l|}{ Primary tillage } \\
\hline MB plough & 0 \\
\hline S.S plough & 0 \\
\hline Kohli plough & 0 \\
\hline Disc plough & 0 \\
\hline Cultivator & 10 \\
\hline Country plough & 18 \\
\hline \multicolumn{2}{|l|}{ Secondary tillage } \\
\hline Spike tooth harrow & 0 \\
\hline Chain harrow & 0 \\
\hline Disc harrow & 0 \\
\hline Rotavator & 2 \\
\hline Puddler & 0 \\
\hline Ridger & 0 \\
\hline Bund former & 0 \\
\hline Leveller & 1 \\
\hline Planker & 4 \\
\hline \multicolumn{2}{|c|}{ Intercultural operation equipments } \\
\hline Long handle hoe & 44 \\
\hline Double end hoe & 22 \\
\hline v- blade hoe & 20 \\
\hline Paddy weeder & 0 \\
\hline Khurpa & 32 \\
\hline Wheel hoe & 0 \\
\hline Gudnu & 78 \\
\hline Bongardi & 79 \\
\hline \multicolumn{2}{|c|}{$\begin{array}{l}\text { Sowing/ transplanting and plant protection } \\
\text { equipments }\end{array}$} \\
\hline Seed drill & 0 \\
\hline Seed cum fertilizer drill & 0 \\
\hline Transplanter & 0 \\
\hline Pora kera & 0 \\
\hline Seed treating drum & 0 \\
\hline Duster cum sprayer & 0 \\
\hline Knapsac sprayer & 25 \\
\hline \multicolumn{2}{|l|}{ Irrigation equipments } \\
\hline Centrifugal pump & 0 \\
\hline Persian wheel & 0 \\
\hline Sprinkle irrigation & 0 \\
\hline Drip irrigation & 0 \\
\hline
\end{tabular}

Figures are percentages and rounded upto nearest whole number 
Table.2 Adoption of harvesting and threshing machinery/ equipments

\begin{tabular}{|l|c|c|}
\hline $\begin{array}{l}\text { Harvesting and post } \\
\text { equipments }\end{array}$ & harvesting & $\begin{array}{c}\text { Total } \\
(\mathbf{n}=\mathbf{1 6 0})\end{array}$ \\
\hline Sickle & & 96 \\
\hline Reaper & & 0 \\
\hline Binder & & 0 \\
\hline Combine harvester & & 0 \\
\hline Potato digger & 0 \\
\hline Power thresher & 0 \\
\hline Seed grader & 0 \\
\hline Wheat thresher & 0 \\
\hline Seed cleaner & 0 \\
\hline Maize sheller & 0 \\
\hline Farm power & \\
\hline Tractor & & 8 \\
\hline Power tiller & & 0 \\
\hline Gobar gas & & 0 \\
\hline
\end{tabular}

Figures are percentages and rounded upto nearest whole number

Table.3 Productivity of crops via different sources of farm power

\begin{tabular}{|l|c|c|c|c|}
\hline \multirow{2}{*}{ Crop } & \multicolumn{4}{|c|}{ Productivity (q/ha) } \\
\cline { 2 - 5 } & Tractor operated & Bullocks operated & Mixed operated & Total $(\mathbf{n = 1 6 0})$ \\
\hline Rice & 32.69 & -- & -- & $32.69 \pm 1.58$ \\
\hline Wheat & 21.65 & 12.82 & 22 & $18.82 \pm 9.02$ \\
\hline
\end{tabular}

Table.4 Factors affecting productivity of wheat

\begin{tabular}{|c|c|c|c|c|c|c|}
\hline \multirow[t]{2}{*}{ Dependent variable } & & & & & & \multirow[t]{2}{*}{ Remarks } \\
\hline & Model & B & Std. Error & $\mathbf{t}$ & Sig. & \\
\hline \multirow{9}{*}{ Wheat productivity } & (Constant) & 17.96 & 0.85 & 21.16 & 0.001 & \multirow{9}{*}{$\begin{array}{l}R^{2}=0.223 \\
f=14.482\end{array}$} \\
\hline & Irrigation & 8.13 & 1.63 & 4.98 & 0.001 & \\
\hline & (Constant) & 19.37 & 0.95 & 20.48 & 0.001 & \\
\hline & Irrigation & 7.74 & 1.59 & 4.86 & 0.001 & \\
\hline & Primary tillage & -3.87 & 1.26 & -3.06 & 0.003 & \\
\hline & (Constant) & 19.59 & 0.93 & 21.01 & 0.001 & \\
\hline & Irrigation & 6.71 & 1.61 & 4.15 & 0.001 & \\
\hline & Primary tillage & -4.49 & 1.26 & -3.55 & 0.001 & \\
\hline & Rotavotor & 13.52 & 5.27 & 2.57 & 0.011 & \\
\hline
\end{tabular}


Table.5 Factors affecting productivity of rice

\begin{tabular}{|l|l|l|l|l|l|l|}
\hline $\begin{array}{l}\text { Dependent } \\
\text { variable }\end{array}$ & \multicolumn{4}{|c|}{ Remarks } \\
\cline { 1 - 2 } & Model & B & Std. Error & t & Sig. & \\
\hline $\begin{array}{l}\text { Rice } \\
\text { productivity }\end{array}$ & (Constant) & 31.73 & 3.74 & 8.48 & 0.001 & $\begin{array}{l}\mathrm{R}^{2}=0.193 \\
\mathrm{f}=2.149\end{array}$ \\
\hline & Primary tillage & 32.51 & 12.56 & 2.58 & 0.011 & \\
\hline
\end{tabular}

In case of wheat, 79.48 percent used tractor for tillagew operation and the productivity was $21.65 \mathrm{q} / \mathrm{ha}, 17.94$ percent of the respondents used bullock for tillage operation and the productivity was $12.82 \mathrm{q} / \mathrm{ha}$ and 2.56 percent used mixed operated (tractor+ bullock) for tillage operation and the productivity was $22 \mathrm{q} / \mathrm{ha}$. The total productivity of wheat in the study area was $18.82 \mathrm{q} / \mathrm{ha}$ (Table 3). These findings are in line with Singh (2008), Rehman et al., (2011) and Kumar and Tawari (2013).

For analyzing the factors affecting productivity of wheat and rice linear regression model was used. The different independent variable taken were cultivator score, rotavotor score, irrigation score, knapsack sprayer score, adoption of primary tillage equipments score, adoption of secondary tillage equipments score, adoption sowing and transplanting equipment score, adoption of intercultural and fertilizer equipments score.

The results revealed that the adoption of irrigation and rotavotor had a positive and significant effect on the productivity of wheat, where as adoption of primary tillage has a negative and significant affect on the productivity of wheat crop. From the value of coefficient of determination, it is concluded that all these variables cause 22 percent variation in the productivity of wheat crop (Table 4). In case of productivity of rice crop as dependent variable, adoption of primary tillage had a positive and significant impact.
The value of coefficient of determination indicates that machinery used for primary tillage caused 19 percent variation in productivity of rice (Table 5). The findings are in line with Bagaheri and Ghorbani (2011), Musa et al., (2012) and Reza and Khan (2013)

In conclusion, agriculture machinery and equipments are an important factor for increase production and productivity of agriculture. There are some direct or indirect effects of agriculture machinery and equipments on productivity through better use of their inputs, more efficient and timely completion of agricultural operations. The study suggest that there must be a provision for farm machinery banks either individually or collectively for custom hiring to provide hiring services for machinery/ equipments used for different agricultural operation.

\section{References}

Bagheri, A. and Ghorbi, A. 2011. Adoption and non adoption of sprinkler irrigation technology in Ardabil Province of Iran. African Journal of Agricultural Research, 6(5): 1085- 1089.

Kumar, S.N. and Tevari, P. 2013. Socio economic dimension of beneficiaries in Kawad watershed development project, International Journal of Scientific Research, 2(3): 2277-8179.

Musa, D.S., Musa, J. and Ahmad, D. 2012. A study on mechanization effect on farm practices in Kwara state, North central 
Nigeria. ISOR Journal of Engineering, 2(3): 79-84.

Singh., et al., 2008, original not seen, cited at page no. $63 \& 64$ in state of Indian agriculture 2011-12.

Rehman, M.S., Miah, M.A.M, Moniruzzaman and Hussain, S. 2011. Impact of farm mechanism on labour use for wheat cultivation in northern Bangladesh. The
Journal of Animal and Plant Sciences, 21(3):589-594.

Reza, M.S. and Khan, M.M.H. 2013. Impact of Farm Mechanization on Productivity and Profitability of Rice Farm in Rajasthan District. Bangladesh Journal of Political Economy, 29(1): 169-188.

\section{How to cite this article:}

Sagir Ahmed, Y.S. Bagal, Rashika Mahajan and Sharma, L.K. 2020. Impact of Farm Mechanization on Crop Productivity in Sub- Tropical Areas of Jammu and Kashmir. Int.J.Curr.Microbiol.App.Sci. 9(05): 1168-1173. doi: https://doi.org/10.20546/ijcmas.2020.905.128 